\title{
INVENTARISASI JAMUR PATOGEN TANAMAN BUAH NAGA (Hylocereus undatus) DI PT. NUSANTARA TROPICAL FARM (NTF) LAMPUNG TIMUR
}

\section{THE INVENTORY OF FUNGI PATHOGENIC ON THE DRAGON FRUIT PLANT (Hylocereus undatus L.) IN PT. NUSANTARA TROPICAL FARM (NTF) EAST LAMPUNG}

\author{
Septa Chandra*, Radix Suharjo, Joko Prasetyo, Efri \\ Jurusan Agroteknologi Fakultas Pertanian Universitas Lampung \\ Jalan Prof. Dr. soemantri Brojonegoro No.1 Bandar Lampung 35145 \\ *E-mail: Septachandra14@gmail.com
}

\begin{abstract}
Increasing production of dragon fruit plants is always necessary to meet consumer needs but the problem of pests and plant diseases is one of the limiting factors for increasing dragon fruit production. Extensive and monocultured planting increases the risk of pest and disease outbreaks. The absence of accurate information about the types of disease that attack is one of the factors causing the problem of this plant disease is difficult to overcome. Lack of information has resulted in suboptimal control measures. Therefore, it is necessary to carry out an inventory of the types of pathogens, so that the control techniques used can be right on target so that the control results can be more optimal. In this study, an inventory was carried out on plant diseases caused by fungi. This research was conducted at the Biotechnology Laboratory, Faculty of Agriculture, University of Lampung. Diseased plant samples were taken at the plantation of PT. Nusantara Tropical Farm (NTF) In Way Jepara District, East Lampung Regency. This research aims to inventory the pathogenic fungi that attack dragon fruit plants at PT. Nusantara Tropical Farm (NTF). The results showed that the fungus that causes dragon fruit disease in PT. Nusantara Tropical Farm (NTF) are fungi Neofusicoccum parvum which causes rust symptoms on the stem of dragon fruit plants with the disease intensity $55.06 \%$, Colletotricum gloesporioides which causes rot symptoms in dragon fruit, Neoscytalidium dimidiatum which causes anthracnose symptoms on the plant stem dragon fruit with the disease intensity $11.67 \%$
\end{abstract}

Keywords: Dragon fruit, fungi inventory, pathogens

\begin{abstract}
ABSTRAK
Peningkatan produksi tanaman buah naga selalu diupayakan untuk memenuhi kebutuhan konsumen, namun seperti halnya tanaman budidaya lainnya, permasalahan hama dan penyakit tanaman juga menjadi salah satu faktor pembatas peningkatan produksi buah naga. Penanaman yang dilakukan secara luas dan monokulturakan meningkatkan resiko terjadinya ledakan hama dan penyakit. Tidak adanya informasi yang akurat tentang jenis
\end{abstract}


penyebab penyakit yang menyerang menjadi salah satu faktor penyebab permasalahan penyakit tanaman ini sulit diatasi. Kurangnya informasi ini mengakibatkan langkah pengendalian yang dilakukan menjadi tidak optimal. Oleh karena itu, perlu dilakukan inventarisasi jenis patogen, agar teknik pengendalian yang nantinya digunakan dapat tepat sasaran sehingga hasil pengendaliannya dapat lebih optimal. Dalam penelitianini, inventarisasi dilakukan kepada penyakit tanaman yang disebabkan oleh jamur. Penelitian ini dilaksanakan di Laboratorium Bioteknologi Fakultas Pertanian Universitas Lampung. Pengambilan sampel tanaman sakit dilakukan di perkebunan PT. Nusantara Tropical Farm (NTF) Di Kecamatan Way Jepara, Kabupaten Lampung Timur.Penelitian ini bertujuan untuk menginventarisasi jamur patogen yang menyerang tanaman buah naga di PT. Nusantara Tropical Farm (NTF). Hasil penelitian menunjukkanbahwa Jamur penyebab penyakit buah naga di PT. Nusantara Tropical Farm (NTF) adalah Jamur Neofusicoccum parvum yang menyebabkan gejala karat pada bagian batang tanaman buah naga dengan tingkat serangan tertinggi 55,06, jamur Colletotricum gloesporioides yang menyebabkan gejala busuk pada buah naga, jamur Neoscytalidium dimidiatum yang menyebabkan gejala antraknosa pada bagian batang tanaman buah naga dengan tingkat serangan tertinggi 11,67\%

Kata kunci: Buah naga, inventarisasi jamur, pathogen

\section{PENDAHULUAN}

Buah naga biasa disantap sebagai buah meja, diolah menjadi puding, isi pai, campuran salad atau es buah. Dibalik rasanya yang manis menyegarkan, buah naga kaya akan manfaat seperti menurunkan kolesterol dan penyeimbang gula darah, pengikat zat karsinogen penyebab kanker dan memperlancar proses pencernaan. Belum ada penelitian pastitentang manfaat buah ini. Namun, banyak orang percaya buah naga mengandung vitamin $\mathrm{C}$,beta karoten, kalsium, karbohidrat, dan tinggi serat (Winarsih, 2007). Buah naga termasuk dalam buah yang eksotik karena penampilannya yang menarik, rasanya asammanis menyegarkan dan memiliki beragam manfaat untuk kesehatan (Sutomo, 2007). Beberapa diantaranya adalah serangan hama kumbang Protaetia impavida dan penyakit busuk batang yang disebabkan oleh beberapa jenis mikroba seperti cendawan dari genus Fusarium, Phytophthora, Sclerotium, Rhizoctonia dan Pythium (Jumjunidang et al., 2012). Terdapat dua penyakit yang paling sering dijumpai hampir di setiap pertanaman buah naga yaitu busuk lunak batang dan antraknosa. Penyakit ini disebabkan oleh Xanthomonas campestris, Fusarium oxysporum, dan Pantoea spp. (SFNS, 2012).

\section{Patogen yang menyerang akar yaitu} Phytophthora sp., Fusarium sp., dan Alternaria sp. (FAO, 2012). Terdapat banyak jenis patogen yang menyerang buah. Cendawan patogen menyerang buah yang berada di pertanaman yaitu Helminthosporium sp., Colletotrichum sp., Curvularia spp., dan Cladosporium spp. Terkadang satu penyakit pada buah disebabkan oleh beberapa patogen tersebut secara bersamaan (Eng, 2012). Cendawan patogen lain yang dapat menyebabkan kerusakan pada buah naga yaitu Fusarium spp. dan Aspergillus spp. (Freitas et al., 2011). Gejala yang terlihat pada perkembangannya yaitu respon terhadap suhu ekstrim, 
paparan sinar matahari, pemupukan tanah yang buruk, praktik irigasi yang tidak layak atau stress lainnya pada tanaman(Merten, 2003). Di Indonesia, tanaman buah naga sudah mulai dibudidayakan sejak tahun 2000. Di provinsi Lampung, PT Nusantara Tropical Farm (NTF) menjadi salah satu perusahaan yang membudidayakan buah naga dalam skala besar untuk keperluan ekspor. Di NTF, buah naga mulai dibudidayakan pada tahun 2012. Hingga saat ini, permasalahan hama dan penyakit, khususnya penyakit tanaman buah naga masih menjadi permasalahan yang belum terpecahkan secara tuntas di PT. NTF. Tidak adanya informasi yang akurat tentang jenis penyebab penyakit yang menyerang menjadi salah satu faktor penyebab permasalahan penyakit tanaman ini sulit diatasi. Oleh karena itu, perlu dilakukan inventarisasi jenis patogen, agar teknik pengendalian yang nantinya digunakan dapat tepat sasaran sehingga hasil pengendaliannya dapat lebih optimal. Dalam penelitian ini, inventarisasi dilakukan kepada penyakit tanaman yang disebabkan oleh jamur.

\section{BAHAN DAN METODE}

\section{Tempat dan Waktu Penelitian}

Penelitian ini dilaksanakan di Laboratorium Bioteknologi Fakultas Pertanian Universitas Lampung. Pengambilan sampel tanaman sakit dilakukan di perkebunan PT. Nusantara Tropical Farm (NTF) Di Kecamatan Way Jepara, Kabupaten Lampung Timur.

\section{Bahan dan Alat}

Bahan-bahan yang digunakan dalam penelitian ini adalah aquades, potato dextrose agar (PDA), alkohol 70\%, dan tanaman buah naga (Hylocereus undatus) yang mengalami gejala penyakit, serta tanaman buah naga (Hylocereus undatus) sehat untuk uji patogenesitas.

Alat-alat yang digunakan dalam penelitian ini adalah cawan petri, autoklaf, jarum ose, bunsen burner, korek api, nampan plastik, tabung erlenmeyer, kapas, plastik wrap, gelas ukur, tabung reaksi, timbangan digital, pinset, mikropipet, laminar air flow, penggaris, kertas label, pisau, alumunium foil, mikroskop, dan alat tulis.

\section{Pelaksanaan Penelitian}

Isolasi. Sampel tanaman buah naga (buah, dan batang) yang menunjukkan gejala penyakit diambil dari perkebunan PT. NTF, Kecamatan Way Jepara, Kabupaten Lampung Timur. Bagian tanaman yang diambil untuk keperluan isolasi dipotong kecil dengan ukuran $2 \times 2 \mathrm{~cm}$ dengan perbatasan $1 / 4$ sakit dan $3 / 4$ sehat.Selanjutnya, potongan tersebut direndam selama 1 menit dalam akuades kemudian dimbil dan didesinfektan dalam 1\% klorok selama 1 menit, kemudian direndam kembali dalam akuades selama 1 menit lalu diangkat dan ditiriskan. Setelah kering potongan ditanam di tengah cawan petri yang berisi media potato Sukrose agar (PSA) (ekstrak kentang (200 gram dalam $800 \mathrm{ml}$ aquades), $20 \mathrm{~g}$ Sukrose, 20 g Agar), ditambahkan aquades hingga 1000 ml, pH 6,8) dan diinkubasi di suhu ruang.

Pemurnian. Dari hasil isolasi, jamur yang tumbuh kemudian dimurnikan. Pemurnian dilakukan dengan memindahkan koloni jamur yang konsisten muncul dari setiap langkah isolasi ke dalam cawan petri yang berisi media PSA. Pemurnian dilakukan terus 
menerus sampai didapatkan koloni murni.

Uji Patogenesitas. Pengujian ini dilakukan untuk memastikan bahwa jamur yang didapatkan merupakan patogen penyebab penyakit buah naga di PT. NTF. Pengujian ini dilakukan dengan cara menginokulasikan isolat murni jamur yang didapatkan pada tanaman inang yang sehat sesuai dengan daerah asal jamur tersebut diisolasi (buah atau batang). Apabila hasil inokulasi menunjukkan gejala yang sama dengan gejala yang ditemukan di lapangan, maka dapat dipastikan jamur tersebut merupakan penyebab penyakit yang ditemukan. Inokulasi dilakukan dengan 4 metode yaitu :

Penempelan. Bagian tanaman buah naga yang akan diinokulasi dilukai (secukupnya) dengan menggunakan jarum steril. Setelah itu, satu potongan bor gabus (diameter $0,5 \mathrm{~cm}$ ) diletakkan pada bagian yang dilukai tersebut dan direkatkan dengan menggunakan selotip. Tanaman kemudian disungkup menggunakan plastik bening dengan ukuran $1 \mathrm{~kg}$ dan diletakkan di dalam rumah plastik, Fakultas Pertanian unila.Pengamatan dilakukan 2 hari sekali selama 14 hari.

Disemprot dan ditusuk. Bagian tanaman buah naga yang akan diinokulasi dilukai (secukupnya) menggunakan jarum steril. Suspensi spora (kurang lebih $10^{8}$ ) isolat murni jamur yang akan diujikan disemprotkan ke bagian tanaman yang telah dilukai tersebut. Tanaman kemudian disungkup menggunakan plastik bening dengan ukuran $1 \mathrm{~kg}$ dan diletakkan di rumah plastik, Fakultas Pertanian Unila. Pengamatan dilakukan 2 hari sekali selama 14 hari.
Disemprot dan tidak ditusuk. Bagian tanaman buah naga yang akan diinokulasi disemprot dengan suspensi spora (kurang lebih $10^{8}$ ) tanpa dilukai dengan jarum steril. Tanaman kemudian disungkup menggunakan plastik bening dengan ukuran $1 \mathrm{~kg}$ dan diletakkan di rumah plastik, Fakultas Pertanian Unila.Pengamatan dilakukan 2 hari sekali selama 14 hari.

Ditusuk tanpa disemprot. Bagian tanaman buah naga yang akan diinokulasi hanya dilukai dengan jarum steril tanpa diberi perlakuan penyemprotan suspensi spora jamur. Tanaman kemudian disungkup menggunakan plastik bening dengan ukuran $1 \mathrm{~kg}$ dan diletakkan di rumah plastik, Fakultas Pertanian Unila.Pengamatan dilakukan 2 hari sekali selama 14 hari.

Identifikasi. Identifikasi dilakukan terhadap jamur yang menghasilkan gejala yang sama dengan gejala yang ditemukan di lapang dan hasil uji patogenesitas. Identifikasi dilakukan dengan mengamati struktur khususnya jamur tersebut di bawah mikroskop.Identifikasi dilakukan hingga tingkat spesies.

\section{Perhitungan Keparahan Penyakit di}

Lapangan. Perhitungan keparahan penyakit ini dilakukan untuk mengetahui tingkat dan perkembangan serangan masing-masing jenis patogen di lapangan. Pengamatan dilakukan terhadap 730 tanaman dari 4533 total tanaman yang ada. Penentuan sampel tanaman yang diamati dilakukan dengan pengacakan (Gambar 1). Pengamatan dilakukan terhadap keparahan penyakit setiap 2 minggu sekali selama 3 bulan. 


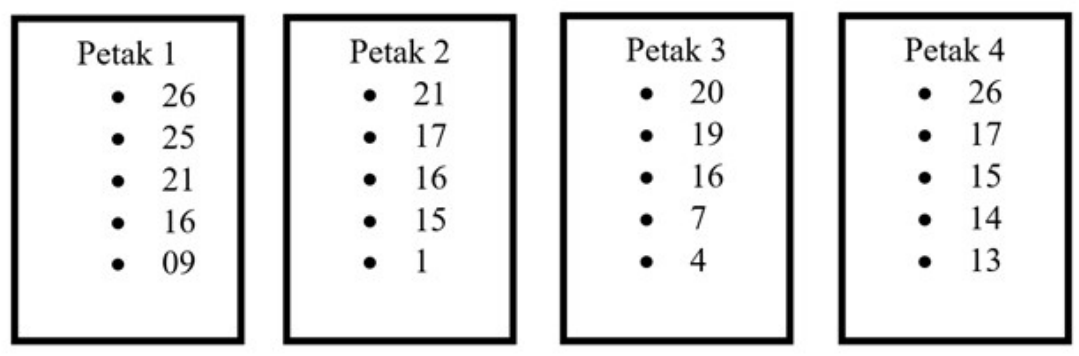

Gambar 1. Tata Letak Sampel yang diamati

Tingkat keparahan penyakit dihitung menggunakan rumus sebagai berikut:

$$
\mathrm{KP}=\frac{\sum n V}{Z N} X 100 \%
$$

Keterangan:

$\mathrm{KP}=$ keparahan penyakit

$\mathrm{n}=$ jumlah tanaman dalam setiap katagori

$\mathrm{v}=$ nilai numerik dari katagori serangan

$\mathrm{Z}=$ katagori serangan dengan nilai numerik tertinggi

$\mathrm{N}=$ jumlah seluruh tanaman yang diamati

\section{HASIL DAN PEMBAHASAN}

\section{Hasil Pengamatan}

\section{Kondisi Kebun Buah Naga di PT. NTF}

PT. NTF memiliki kebuh buah naga dengan luas sekitar 5 Ha yang terbagi menjadi 4 plot atau petak. Setiap petak ada sekitar 30 baris yang setiap barisnya ditanami 30 tanaman buah naga. Varietas buah naga yang digunakan di PT. NTF adalah super red. Kondisi dikebun buah naga PT. NTF sangat terawat mulai dari pembersihan gulma sampai pemangkasan yang dilakukan untuk merangsang pertumbuhan buah naga dan pengendalian penyakit. Tanaman buah naga dapat berproduksi setelah umur tanaman 2-3 tahun dengan masa berbunga setiap 4-5 bulan sekali.

\section{Jenis Penyakit yang ditemukan dilapangan}

Penyakit yang ditemukan pada bagian buah naga di PT. NTF yaitu busuk buah yang memiliki gejala berupa busuk pada bagian kulit buah naga (Gambar 2).

Pada bagian batang didapatkan dua gejala yang berbeda gejala karat dan antraknosa. Gejala penyakit karat yang ditemukan dilapangan berupa bercak pada bagian batang buah naga (Gambar 3). Kemudian pada gejala seperti antraknosa yang ditemukan dari lapangan berupa bulatan berwarna hitam dengan kering pada bagian pinggirnya (Gambar 4).

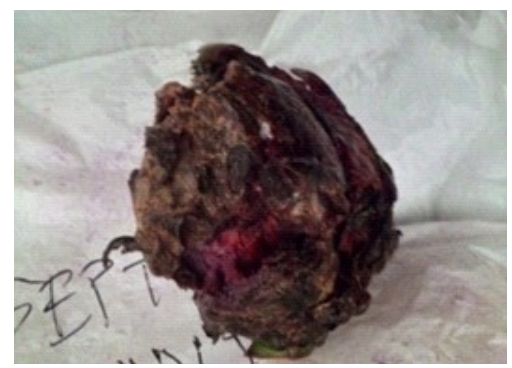

Gambar 2. Gejala Busuk Buah di Lapangan

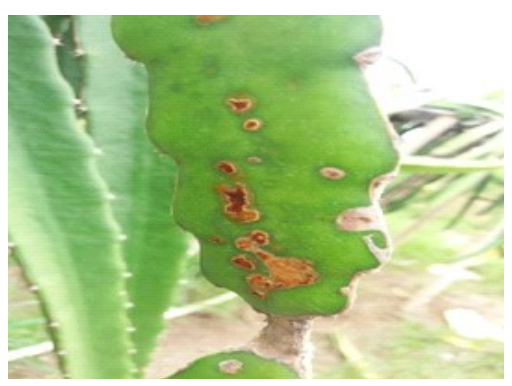

Gambar 3. Gejala Penyakit Karat di Lapangan 


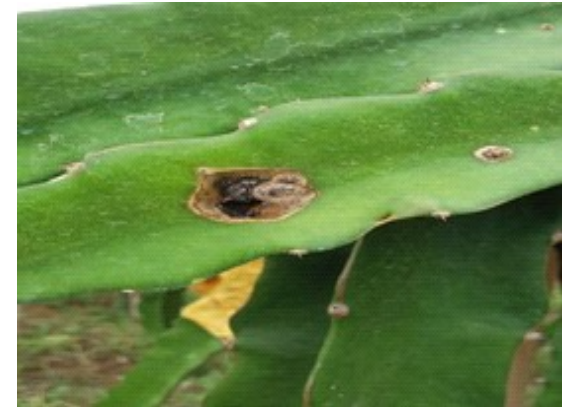

Gambar 4. Gejala Penyakit Antraknosa di Lapangan

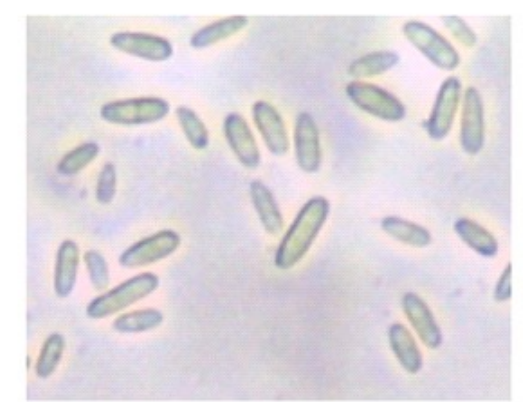

(A)

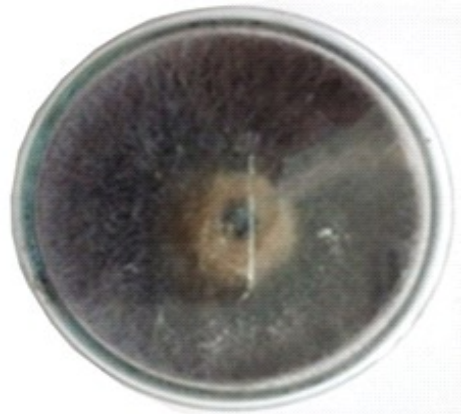

Gambar 5. Koloni Jamur yang diduga patogen penyebab penyakit busuk buah

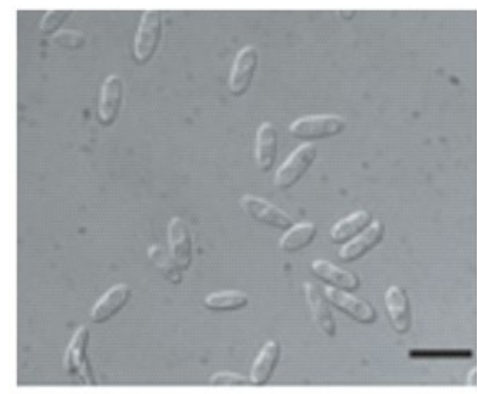

(B)

Gambar 6. Kenampakan Mikroskopis Spora (A) jamur yang ditemukan (B) Spora JamurColletotrichum gloeosporioides menurutThan etal (2008).

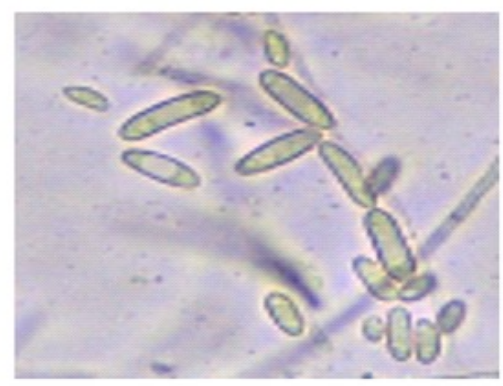

(A)

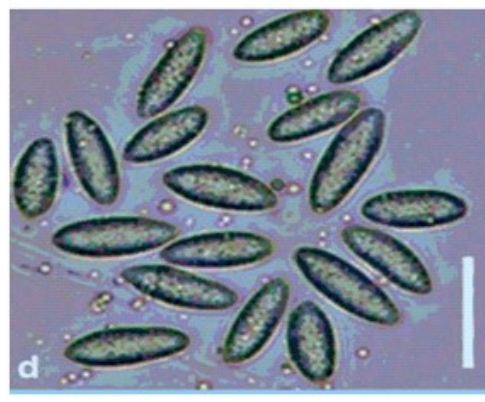

(B)

Gambar 8. Kenampakan Mikroskopis Spora (A) Jamur yang ditemukan (B) Spora Jamur Neofusicoccum parvum Menurut Ji-Ye Yan et al. (2013).

\section{Hasil Isolasi Pada Bagian Buah}

Hasil isolasi dari bagian buah naga didapatkan beberapa jenis jamur, tetapi hanya ada satu jamur yang konsisten muncul. Pada setiap kali isolasi jamur tersebut mempunyai koloni berwarna hitam (Gambar 5). Hasil pengamatan mikroskopis didapatkan konidia berbentuk lonjong agak memanjang. Menurut Than et al. (2008), spora jamur ini identik dengan jamur Colletotrichum gloeosporioides (Gambar 6).

\section{Hasil Isolasi Pada Bagian Batang}

Gejala Karat. Dari gejala karat didapatkan jenis jamur dengan ciri-ciri koloniberwarna putih(Gambar 7). 
Hasil pengamatan mikroskopis didapatkan konidia berbentuk oval agak memanjang. Bentuk spora yang ditemukan tersebut identik dengan spora jamur Neofusicoccum parvum menurut Ji-YeYan etal. (2013) (Gambar 8). Perbandingan ciri- ciri jamur yang ditemukan dengan ciri- ciri jamur Neofusicoccum parvum menurut Ji-Ye Yan et al. (2013).

Gejala antraknosa. Dari gejala antraknosa ditemukan satu jamur yang konsisten muncul dengan koloni berwarna hitam (Gambar 9).

Hasil pengamatan mikroskopis didapatkan spora berbentuk seperti rantai dan bersekat. Menurut Dionne et al. (2015) ciri-ciri spora tersebut identik dengan spora jamur Neoscytalidium dimidiatum (Gambar 10).

Patogenesitas. Patogenesitas yang dilakukan terbagi menjadi dua bagian, bagian pertama berupa patogenesitas pada buah, bagian kedua pada batang.

Patogenesitas pada buah. Hasil uji patogenesitas pada buah naga yang ditempelkan dengan jamur hasil isolasi dari buah naga didapatkan gejala berupa busuk kering. Gejala mulai muncul 4 hari setelah inokulasi (Gambar 11).

\section{Patogenesitas pada batang buah naga. Uji} patogenesitas pada bagian batang dilakukan dengan beberapa metode : penempelan dengan jamur hasil isolasi, disemprot dan ditusuk, disemprot tidak ditusuk dan ditusuk tidak disemprot.

\section{Hasil Patogenesitas Jamur}

Neofusicoccum parvum Dari hasil semua metode yang digunakan dalam pengaplikasian jamur Neofusicoccum parvum hanya ada 2 metode yang mengeluarkan gejala yaitu metode penempelan dan

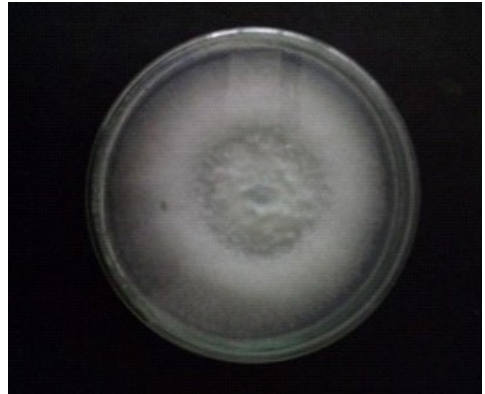

Gambar 7. Koloni Jamur yang ditemukan.

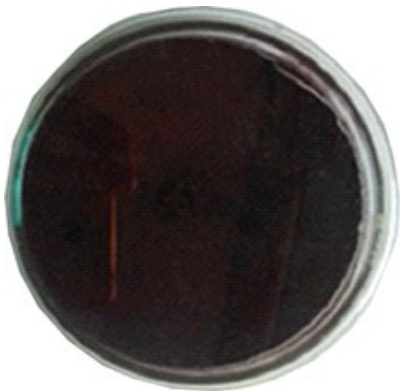

Gambar 9. Koloni Jamur Neoscytalidium dimidiatum

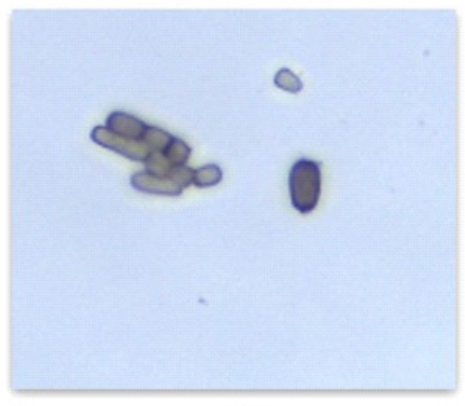

(A)

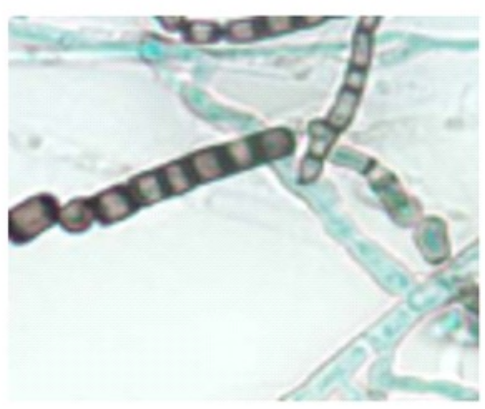

(B)

Gambar 10. Kenampakan Mikroskopis Spora (A) Jamur yang ditemukan (B) Spora Jamur Neoscytalidium dimidiatum Menurut Dionne et al. (2015). 
metode ditusuk dan disemprot. Akan tetapi metode yang mengeluarkan gejala seperti dilapangan hanya metode penempelan dengan ciri-ciri gejala seperti karat berwarna kuning kemerahan (Gambar 12).

\section{Hasil Patogenesitas Jamur Neoscytalidium}

dimidiatum pada metode : Dari hasil semua metode yang digunakan dalam pengaplikasian jamur
Neoscytalidium dimidiatum hanya ada 2 metode yang mengeluarkan gejala yaitu metode penempelan dan metode ditusuk dan disemprot. Akan tetapi metode yang mengeluarkan gejala seperti dilapangan hanya metode penempelan dengan ciri-ciri gejala seperti antraknosa berwarna hitam dibagian tengah dan busuk pada bagian tepi (Gambar 13).

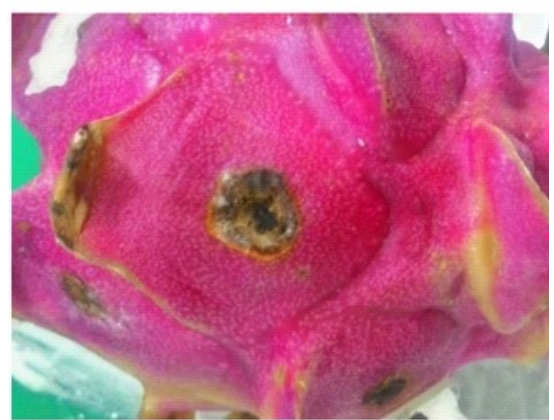

(A)

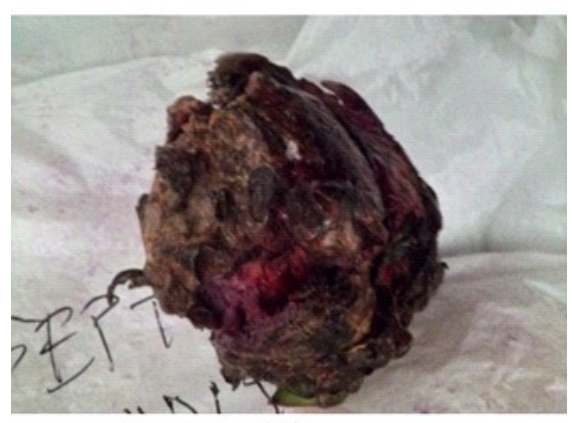

(B)

Gambar 11. Hasil penempelan Jamur Pada Buah Naga (A) Hasil Patogenesitas Colletotrichum gloeosporioides, (B) gejala dari lapangan

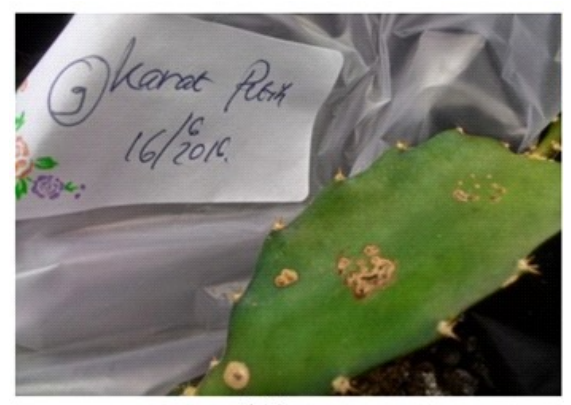

(A)

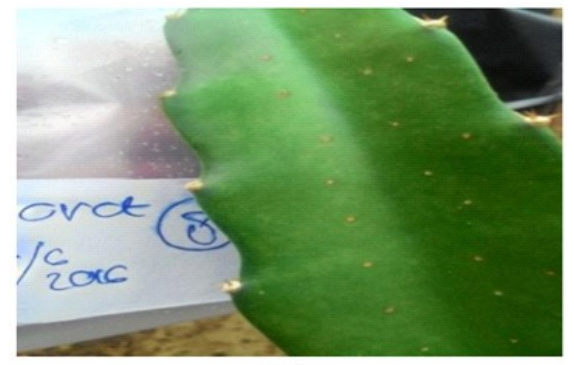

(C)

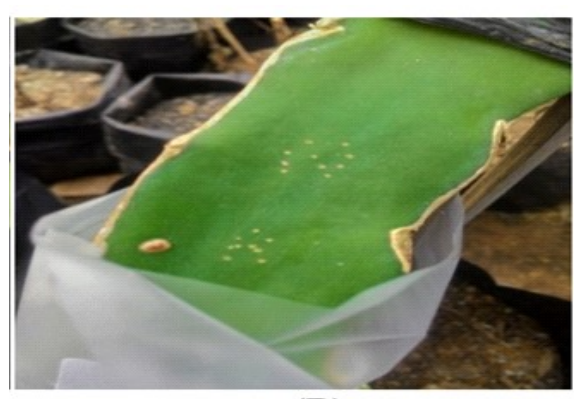

(B)

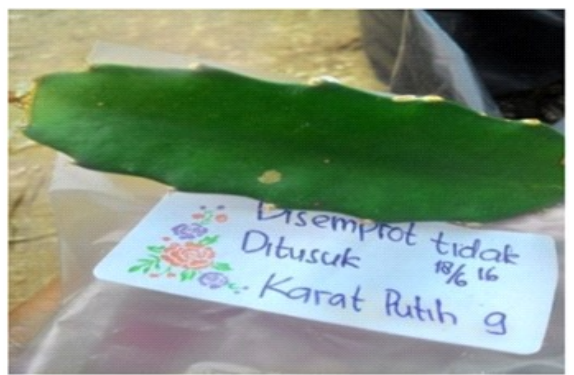

(D)

Gambar 12. Hasil patogenesitas jamur Neofusicoccum parvum (A) Penempelan, (B)Ditusuk tidak disemprot suspensi Jamur Neofusicoccum parvum (C) Ditusuk dan di semprot (D)Disemprot suspensi jamur Neofusicoccum parvum dan tidak ditusuk. 


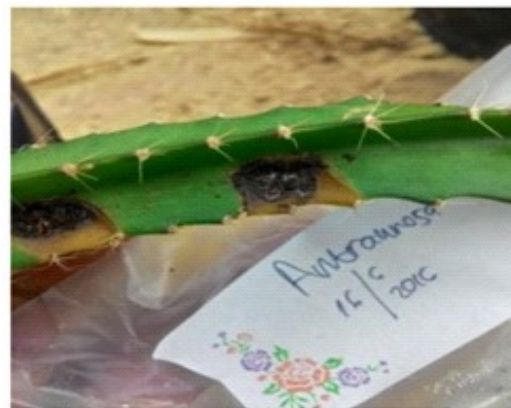

(A)

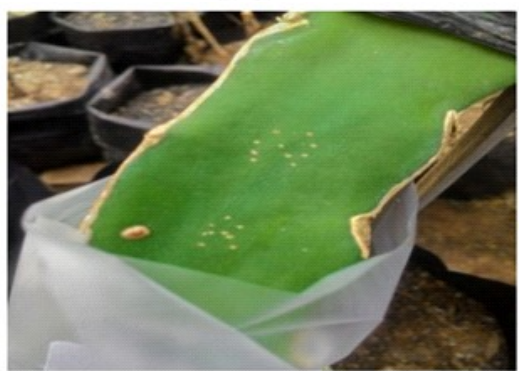

(C)

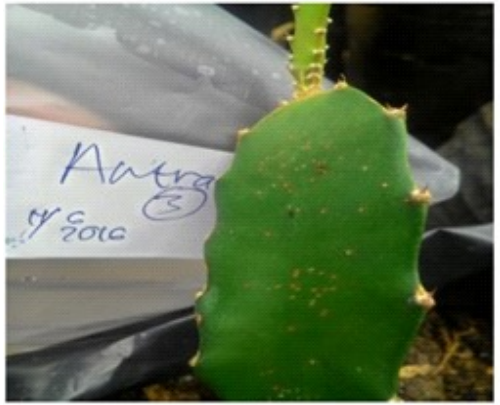

(B)

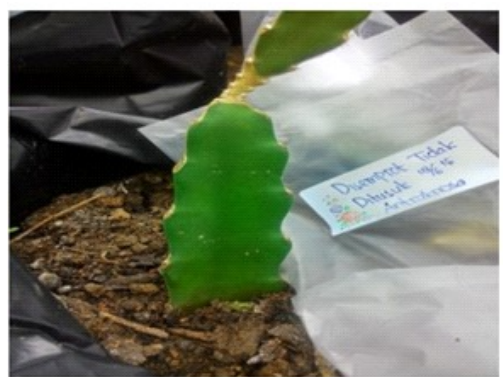

(D)

Gambar 13. Hasil patogenesitas dengan metode (A)Penempelan, (B) Ditusuk dan disemprot Jamur Neoscytalidium dimidiatum (C)Ditusuk dantidakdisemprot, (D)Disemprot suspensi jamur Neofusicoccum parvum dan tidak ditusuk.

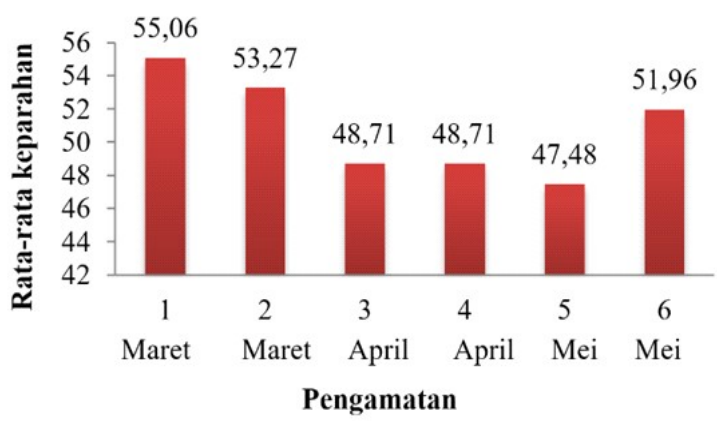

Gambar 14. Keparahan jamurNeofusicoccum

Keparahan penyakit. Keparahan penyakit dihitung berdasarkan gejala yang ditimbulkan oleh jamur pada buah dan batang yang ada dilapang.

Berdasarkan Gambar. 14 keparahan yang telah didapat, keparahan penyakit karat yang diamati di lapangan selama 6 kali pengamatan dengan selang waktu 2 minggu pada tiap kali pengamatan menunjukkan bahwa keparahan penyakit paling tinggi terjadi pada pengamatan pertama sebesar $55,06 \%$,

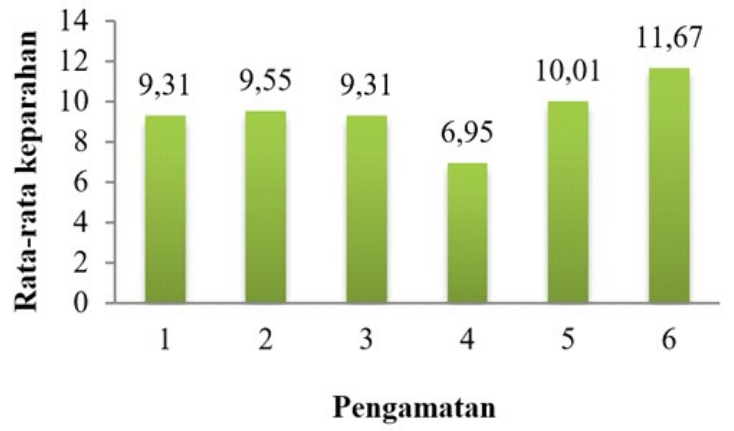

Gambar 15. Keparahan Jamur Neoscytalidium

sedangkan keterjadian penyakit karat terjadi penurunan yang siknifikan pada bulan April-Mei. Menurut grafik yang diatas keparahan atau perkembangan penyakit karat pada tiap pengamatan cenderung menurun, hal ini disebabkan oleh beberapa faktor salah satunya diduga karena adanya penurunan curah hujan pada bulan April sebesar $243 \mathrm{~mm}$ dan bulan Mei sebesar $120 \mathrm{~mm}$ (Lampiran). Kegiatan panen yang sering dilakukan dimana kegiatan tersebut tidak hanya 
memanen buah naga melainkan memangkas batangbatang buah naga yang dianggap memiliki gejala penyakit yang dianggap sudah cukup serius, sehingga perkembangan penyakit pada tiap pengamatan mengalami penurunan. Faktor lain yang menyebabkan pada pengamatan terakhir terjadi peningkatan dalam hal keparahan penyakitnya adalah sedikit sekali kegiatan pemanenan karena buah naga belum banyak yang matang dan siap panen sehingga secara tidak langsung berpengaruh dalam hal peningkatan perkembangan penyakit karena tidak ada bantuan manusia dalam hal memangkas bagian tanaman yang bergejala penyakit.

Berdasarkan Gambar 1 keparahan diatas menunjukkan perkembangan penyakit antraknosa yang paling tinggi berada pada pengamatan $11,67 \%$ pada pengamatan terakhir sedangkan keparahan penyakit antraknosa yang paling rendah ada pada pengamatan keempat sebesar 6,95\% hal ini diduga dapat terjadi karena adannya penurunan curah hujan pada bulan April sebesar $243 \mathrm{~mm}$ (Lampiran) sekaligus pemangkasan bagian tanaman buah naga yang terserang jamur Neoscytalidium dimidiatum.

\section{KESIMPULAN}

Berdasarkan hasil penelitian dapat disimpulkan bahwa Jamur penyebab penyakit buah naga di PT. Nusantara Tropical Farm (NTF) adalah gejala karat pada batang buah naga disebabkan oleh Jamur Neofusicoccum parvumdengan persentase serangan sebesar 55,06 \%. Gejala busuk pada buah naga disebabkan oleh Jamur Colletotrichum gloesporioides.
Gejala antraknosa pada bagian batang buah naga disebabkan oleh Jamur Neoscytalidium dimidiatum dengan persentase serangan sebesar 11,67\%.

\section{DAFTAR PUSTAKA}

Dionne, B., N. Luke., A.L. Samuel., A.S. Deanna., P.W. Nethan., L.Jonethan.,\& F. Hongxin. 2015. Pulmonary Fungal Infection Caused by Neoscytalidium dimidiatum. Journal of Clinical Microbiology. 53(7) : 2381-2384.

Eng, L. 2012. Disease Management of Pitaya. Department of Agriculture Sarawak. http:// www.doa.sarawak.gov.my/modules/ web/ page.php?id=454. Diakses pada tanggal 8 Januari 2016.

[FAO] Food and Agriculture Organization. 2012. Fruit of Vietnam. FAO Corporete Document Repository. http://www.fao.org/docrep/008/ ad523el ad523e05.htm. Diakses pada tanggal 8 Januari 2016.

Freitas, S.T.D., N.T. Nham \& J.E. Mitcham. 2011. Pitaya (pitahaya, dragon fruit) recommendetions for maintaining postharvest quality. Department of Plant Sciences. University of California. http:// postharvest.ucdavis.edu. Diakses pada tanggal 8 Januari 2016

Ji-Ye Yan., Yue Xi e., Wei Zhang., Yong Wang., JianKui Liu., Kevin D. Hyde., Robert C. Seem., Guo-Zhen Zhang., Zhong-Yue Wang., ShengWei Yao., Xian-Jin Bai., Asha J. Dissanayake., You-Liang Peng \& Xing-Hong Li. 2013. Species of Botryosphaeriaceae involved in grapevine dieback in China. Fungal Diversity. 61: 221-236. 
Jumjunidang, Riska \& I. Muas. 2012. Outbreak penyakit busuk batang tanaman buah naga di Sumatera Barat. Laporan hasil survey OPT disentra produksi buah naga Sumatera Barat. Balitbu Tropika Solok . http ://balitbu.litbang. deptan.go.id/ind/index.php/ berita-mainmenu26/13info-aktual/336-outbreak-penyakitbusuk-batang-tanaman-buah-nagadisumatera-barat. Diakses pada tanggal 8 Januari 2016.

Merten, S. 2003. A review of Hylocereus production in the United States. Journal PACD . 5:98-105.

[SFNS] The Sarasota Fruit \& Nut Society. 2010. Pitaya Diseases. http://www. Sarasota fruit and nut society.org/ information/Tropical Fruit/ dragon fruit diseases.htm. Diakses pada tanggal 10 Januari 2016.

Sutomo, B. 2007. Buah Naga Merah Segar dan Berkhasiat. http://myhobbyblogs.com. Diakses pada tanggal 13 Januari 2016.

Than, P. P., R. Jeewon, K. D. Hydet, S. Pongsupasamit., O. Mongkolporn \& P. W. J. Taylor. 2008. Characterization and pethogenicity of Colletotrichum species associeted with anthracnose on chilli (Capsicum spp.) in Thailand. Plant Pathology. 57: 562-572.

Winarsih, S.2007. Mengenal dan Membudidayakan Buah Naga. CV Aneka Ilmu. Semarang. 